\title{
Issues in Doctoral Studies - Forty Years of Discussion: Where have we been and where are we going?
}

\author{
Michael Jones \\ University of Wollongong, Wollongong, Australia
}

mjones.michael@gmail.com

\begin{abstract}
The scrutiny of doctoral studies as a field of academic research and discussion is relatively new, but it is growing quickly. An understanding of what has been said and why is important because it helps us to comprehend recurring themes and issues. This paper examines 995 papers written on issues of doctoral studies through the years 1971 to 2012. Thematic analysis of these papers presents six central themes through which the management and training of doctoral students has been embodied. This paper expands on this analysis to unveil the roads we have travelled and the paths we are yet to travel down, and importantly the issues which have not been fully explored, and thus - continuing with this metaphor - remain uncharted.
\end{abstract}

Keywords: Doctoral Program Design, Doctoral student experience, Employment \& Career, student-supervisor relationship, Teaching, Writing and Research

\section{Biography}

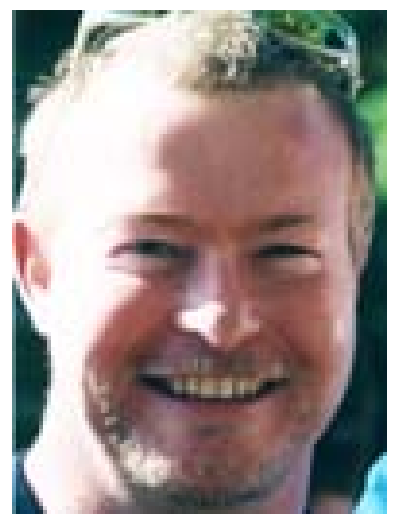

Michael Jones (BComm (hons), PhD.) has been an academic teaching and researching in areas of organisation, business and management for eight years. Michael has developed research interests in the following areas: organisational psychology and behaviour - looking at commitment and motivation and group dynamics. Michael is also developing research strengths in areas of qualitative analysis and has written several papers on various qualitative methodologies and methods. Michael is also interested in research areas such as knowledge management and organisational learning. Michael is also a co-investigator on a major research project explore competitive analysis in the Australian Marine Industry.

Michael is a member of the Australia and New Zealand Academy of Management, the Australian Human

Material published as part of this publication, either on-line or in print, is copyrighted by the Informing Science Institute. Resources Institute, and the Industrial Permission to make digital or paper copy of part or all of these Relations Society of Australia.

works for personal or classroom use is granted without fee provided that the copies are not made or distributed for profit or commercial advantage AND that copies 1) bear this notice in full and 2) give the full citation on the first page. It is permissible to abstract these works so long as credit is given. To copy in all other cases or to republish or to post on a server or to redistribute to lists requires specific permission and payment of a fee. Contact Publisher@InformingScience.org to request redistribution permission.

The full version of this paper will be published in

The International Journal of Doctoral Studies 